
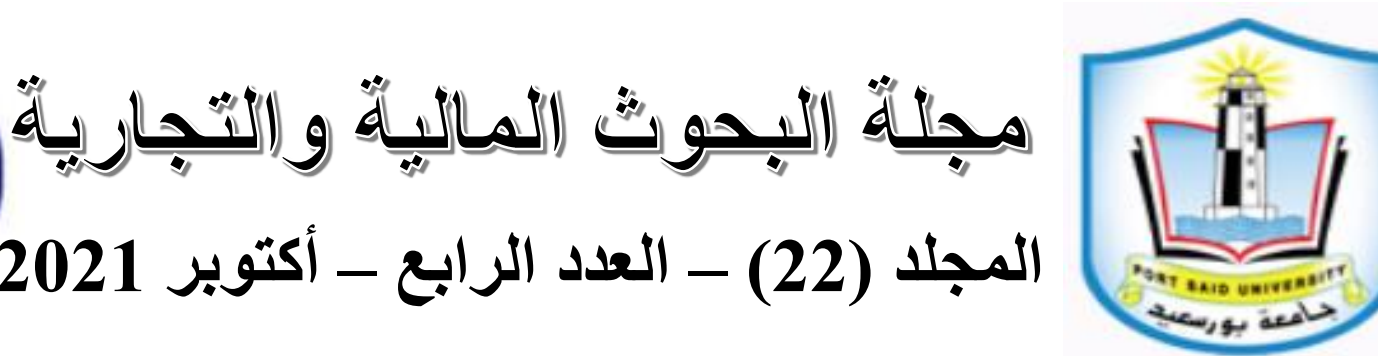

\title{
Democratization in Morocco: The Role of the Monarch
}

\author{
Co-authored by \\ Dr. Mohamed S. M. Hussein \& Munawer Abdullateef AL- Otaibi \\ (PhD in International Relations) (PhD Candidate) \\ Faculty of Economics\& Political Science \\ Cairo University - Egypt \\ October 2020
}




\begin{abstract}
The Kingdom of Morocco has been democratizing steadily since the reign of King Al-Hassan II which started in 1961, and its democracy appears to be advancing, flourishing, and stable. Morocco didn't encounter any extremist or progressive change in 2011 and it doesn't appear to be pursuing the direction of the Arabic Spring. Nor did it appear to be following the regular strides of the progress worldview (advancement, forward leap, and union) laid out by political researchers who handled democratization. Morocco isn't inflexible and has, in this way, to remain with the current the state of affairs; regardless of whether its majority rules system is very recognizable. One of the notable qualities of Moroccan majority rule government is that it contrasts from other vote based system in the Arab, African or underdeveloped nations. Accordingly, it very well may be viewed as a third method of democratization, frequently alluded to as the Moroccan superiority, which is formed by numerous elements that incorporate the part of the Monarch.
\end{abstract}

\title{
Key words:
}

African politics, Moroccan Politics, Comparative politics, democratization, 


\section{Introduction:}

The Kingdom of Morocco has been democratizing under the reign of King Muhammad VI since1999, and its democracy appears to be advancing, and stable. One of the salient traits of Moroccan democracy is that it differs from other democracy in the Arab, African or Third World countries. It very well may be viewed as a third method of democratization regularly alluded to as the Moroccan excellence, which is formed by numerous variables that incorporate the job of the Monarch. This paper, focuses on the role of the king in the democratic process in Morocco.

\section{I- Methodology:}

The paper proceeds by making assessment of the Moroccan political regime and the roles played by different actors in it. It is based on theoretic academic writings and field work (a series of interviews). The field work defied a trouble on account of the incapability of men in the designs picked for the field work. The meetings went between 45 minutes and 1.5 hours in term, were led in different urban communities of Morocco and included delegates from all areas of society. The interviews were not recorded. The questionnaire focused on the democratization process. There are inborn issues in the idea of the homegrown and the global political economy of African States, which may fundamentally vitiate or sabotage vote based dependability in Morocco.

\section{1- Research problem:}

Democratization in Morocco faces serious problems and challenges such as, the power of the king; electoral malpractices, pre-bendalism, political God-fatherism, patro-clientalism; structural and organizational malfunctioning. The study is designed to identify such problems and their solutions.

\section{2- Objectives:}

The objectives are: a- To identify the problems faced by Moroccon democratization; b- To assess the level of these problems; c- To examine Democratization; and d- To identify the challenges that face the kingdom.

\section{3-Scope:}

The study is meant to explore the process of Democratization in Morocco with specific interest in identifying the role of Mohamed VI in it.

\section{4-Significance:}

This paper attempts to $\mathrm{X}$ ray the meaning of both liberal and African democracy, their problems and proper necessary solutions 
5- Theoretical Framework includes:

a- The World System Theory as introduced it explains the pattern, the nature and the shape international relations take in its association in the International System. It helps us identify the Moroccan relations with the European Union in particular.

b-Democratic Peace Theory: which sets that majority rules systems are reluctant to take part in equipped struggles with other distinguished popular governments. Rather than hypotheses clarifying conflict commitment, it's anything but a "hypothesis of harmony" laying out intentions that prevent state-supported viciousness. In this hypothesis, a few elements stand apart as persuading harmony between liberal states: 1-Democratic pioneers are considered liable for war misfortunes to people in general; 2-Democratic legislators are more disposed to set up political foundations for settling worldwide strains; and 3-Democracies are less disposed to see nations with comparable approach and teachings as threatening. In the vote based harmony hypothesis, a few elements stand apart as spurring harmony between liberal states:1-Democratic pioneers are considered dependable to people in general for war misfortunes; 2-Democratic legislators are more disposed to set up strategic establishments for settling worldwide strains; 3Democracies are less disposed to see nations with comparative strategy and conventions as antagonistic; 4-Democracies will in general have more noteworthy public abundance than different states, and subsequently shun battle to save foundation and assets. The individuals who debate the hypothesis regularly do as such on grounds that it conflates relationship with causation .

\section{II-African Democratization :}

Fukuyama's significant work on "The End of History" addresses a universalist situation on liberal vote based system as the model of popularity based government material anyplace on the planet. With the breakdown of socialism and the "triumphant" rise of the USA from the Cold War, Fukuyama announced the liberal (for example popularity based) state as all around successful. He contends that mechanical advancement fundamentally follows an all-inclusive example that is set by the main industrialist economies of the West-an interaction which will "ensure" an "expanding homogenization of every human culture, paying little mind to their verifiable beginning or social legacies" (Fukuyama 1992, p.xiv). He guarantees that all nations going through financial modernization "should progressively look like each other and should bring together broadly based on a concentrated state, urbanize, supplant conventional types of social association (like clan, 
faction and family) with monetarily levelheaded ones dependent on capacity and proficiency, and accommodate widespread training of their residents" (Fukuyama 1992, p..xv). He reasons that the end has come for the battle between various belief systems, in light of the fact that the universalization of Western liberal popular government has won over other challenging majority rule and monetary alternatives. This investigation suggests that African states can't however receive liberal majority rule government with its financial connections to private enterprise .

A particularly universalist view can be viewed as imperialistic endeavoring at developing another picture for underdeveloped nations. For while vote based system could have some general highlights, the introduction of liberal majority rule government as the political medium to safeguard underdeveloped nations out of its assorted issues can be viewed as a bundle of neocolonialism. Additionally, Fukuyama's liberal popular government can't be the finish of mankind's set of experiences; just on the grounds that we are not toward the finish of human knowledge. Various countries (as the instance of Morocco represents) reserve each option to develop new originations of majority rules system, which react to their strict, monetary, and social necessities. Like Fukuyama; Sophie Jane contends that liberal vote based system has the innate possibility of ensuring improvement in Africa (Jane: 2002, 17). He sees the motivation behind why Africa is by all accounts neglecting to democratize is that numerous African states are quickly attempting to merge their majority rules systems and are fretful to accomplish the formative speed of the west. He attests that in more established vote based systems in the West a few conditions have worked with their turn of events and solidified their popular governments. These are: 1-Economic thriving and equity (upgraded by early industrialization); 2-An advanced and expanded social design in which a working class assumes an essential part; 3-A public culture that endures variety and favors convenience, and quite a while length of rehearsing majority rules system .

Today, notwithstanding, the pre-states of the more seasoned vote based systems don't win in Africa as numerous African states are attempting to merge their popular governments, anxious to copy the advancement speed of the west:, "Majority rule government in many pieces of Africa is as yet in its early stages, with poor and at times ethnically separated conditions" (Jane: 2002, 19). It isn't right to imagine that specific societies are innately unfriendly to popularity based qualities and foundations; $\mathrm{f}$ or "A basic examination of the development of the vote based thought and rehearses, and of the worldwide advances of vote based system in administration, propose 
that vote based administration offers to and outgrows the widespread human upsides of respect and opportunity. Where popularity based administration has fizzled, it has done so more because of flawed organizations instead of to the 'unripenness' of a given state. Majority rule government gets inflexible, bad and lethargic without intermittent change and restoration" (Lipset 2000, $10 .($

Popular government is old yet this doesn't imply that it is probably going to be steady. Since quite a while ago settled vote based systems face their own difficulties. Also, in combined popular governments, there is a developing pattern of disregard among citizens, especially the youthful, though in arising majority rules systems elector turnout will in general be high, and numerous vote based developments are driven by youth. In fact, neighborhood societies and customs sway upon the manner in which vote based qualities and frameworks are constructs and upheld.

\section{III- Meaning of Democracy:}

The above origination of popular government has been tested by the individuals who contended that without viable certifications of common freedoms, races don't comprise majority rules system, and that a "procedural least" for characterizing vote based system should incorporate races, yet sensibly wide assurances of fundamental social liberties like right to speak freely, affiliation and get together. They have distinguished further qualities that should be available for these fundamental systems to definitively establish a popular government. Robert Dahl, for example, progresses three fundamental conditions for the well-working multiparty popular government. These are: a) broad rivalry by political competitors and their gatherings or gatherings; b) political support that gives the decision to the electorate to choose applicants in free and reasonable races; and c) common and political freedoms that empower residents to put themselves out there unafraid of discipline (Dahl 1971,221). Larry Diamond, considers majority rules system to be enveloping "not just a non-military personnel, established, multiparty system, with normal, free and reasonable races and widespread testimonial, however authoritative and educational pluralism; broad common freedoms (opportunity of articulation, opportunity of the press, opportunity to shape and join association); compelling force for chose authorities; and utilitarian self-sufficiency for administrative, chief and legal organs of government" (Diamond 1988, 33).

\section{IV.-On the Causes of Democratization: A Theoretical Argument:}

Many scholars attempted to determine what causes democratization in non-democratic or authoritarian countries and studied the relationship between democracy and many other social variables such as: development, 
religion, and the will of the leaders and elite. They saw the models of democratization as communications among elites and residents and discovered that there have consistently been two contrasts that may impact democratization: the recorded period it happens in and the kind of system that popular government expects to supplant (Geddes: 2013, 11). Their research has advanced increasingly to the extent that what we think we know about 'democratization' has changed drastically. Such arguments are quite relevant to democracy in Morocco as their research explored the relationship between democratization and other variables, but most of their findings have been inconclusive and faced many challenges. Their findings confirmed that "richer countries are more likely to become democratic; and that development is conducive to (while poverty hinders) democratization"(Przeworski et al.: 2000, 30). Controversy has never abated about such findings (i.e. about economic development and the likelihood of transition to democracy). Some scholars argue that development does not cause democratization; rather, development reduces the likelihood of democratic breakdown which increases the number of rich democratic countries even though it has no causal effect on transitions to democracy (Ibid).

Attempting to find a link between development and transitions to democracy, a few researchers went over a few exact discoveries that have fortified their contentions however not without challenges. They progressed contentions such that dependence on oil, and maybe other mineral fares, decreases the probability of majority rules system (Stokes: 2003, 12). This has been disputed as Middle East experts explained the correlation between oil wealth and dictatorship as a consequence of a rentier state that uses its rents from the sales of natural resources to distribute subsidies to large parts of the population so as to elicit popular support and legitimacy (Barro: 1996, 158-183). The relationship between oil rents and democracy has been also debated: Dunning, argues that: "oil rents can in some circumstances be used to sustain democracy" (Dunning: 2006, 11).

However, Herb shows that: "when a measure of development excludes the effect of oil on the economy is used in place of GDP per capita in statistical analysis of the causes of democratization, oil-rich countries fit the same patterns as other countries" (Herb: 2005, 297-317). The inference is that development has a strong positive effect on democratization, while rent dependence, considered separately, has no effect (Ross: 1997, 325-6). In short, Herb challenges the existence of a relationship between oil wealth and regime type (Herb: 2005, 298). Weiner and Payne, among others, have suggested that regime type matters when it comes to democratization. They 
claimed that British colonial heritage contributes to better prospects for democracy (Weiner: 1987, 3-5).

Similarly, controversy continues among scholars about whether the relationship between development and democracy is a 'causal' or merely a 'correlational' relationship to be explained by other factors. Among those who believe these relationships are causal, there are disagreements about the processes through which the causes produce the outcome (Sweet: 2001, 2225). A few scholars advanced some arguments about Al-Islam and democratization; emphasizing that Muslim countries (where large Muslim populations reside) were considered less likely to be democratic; thereby suggesting the existence of a relationship between Al-Islam and authoritarianism. They postulated that "Al-Islam is not conducive to democracy"; without even proving such an argument. However, many fair and objective scholars tended to deny any relationship between Islam and authoritarianism; thereby conceding that Islam may not hinder democratization. On the contrary, some of them even argued that Al-Islam may enhance the chances for democratization (Fish: 2002, 4-37). Some scholars insisted that "modernization automatically causes democracy" (Lipset:1959, 69-105). Yet, evidence coming from the studies conducted on African states suggested that modernization theories faltered and could not help the African countries to achieve their developmental goals. Nor were such theories able to help African countries to retain and protect what they have already achieved of these goals (Anderson:1987, pp.1-18).

Many issues like dictatorship, Economic development, transition probabilities to democracy have been studied by political scientists who explored what makes political systems rise, suffer, and fall. The primary inquiry they handled was whether the noticed cozy connection between levels of monetary turn of events and the frequency of majority rule systems was because of popular governments being bound to arise or just get by in the more evolved nations Having assembled information from 135 nations that existed whenever somewhere in the range of 1950 and 1990, they tracked down that the degree of financial advancement didn't influence the likelihood of changes to vote based system however that thriving made vote based systems more steady. They found that fascisms are bound to get by in well off nations and that modernization couldn't without anyone else produce popular government which endures and flourishes in nations that are present day (Przeworski and Limongi: 1997, 155-183). Along these lines, the connection among modernization and vote based system enthused scholarly discussion over the issue on the grounds that there are speculations that help monetary development as both a circumstances and logical results of majority rule government. "Lip set's perception that majority rules system is 
identified with financial advancement has created the biggest collection of exploration on any point in near legislative issues" (Tipps: 1973,199-226). Precious stone contends that monetary exhibition influences the advancement of popular government the same: First, financial development is more significant for vote based system than given degrees of financial turn of events; Second, financial improvement produces social changes that can conceivably work with democratization; and Third, financial improvement advances different changes, similar to association of the working class, are helpful for vote based system (Diamond: 2002. 21-35). "The different parts of monetary turn of events, industrialization, urbanization, riches and instruction, are firmly interrelated and structure one main consideration that corresponds with democracy"(Lipset: 1959, 12) .

A few pundits contended that the connection among modernization and majority rules system depended on models from European history (as in Germany where modernization happened before democratization) and ignored the third world (Apter:1966, 638-640). They keep up that" political systems don't change to popular government according to capita wages rise. Maybe, vote based changes happen arbitrarily and nations with more significant levels of GDP per capita stay popularity based. Epstein retested the modernization theory utilizing new information, new methods, and new characterization of systems (Epstein et. al 2006: 551-569). As opposed to the contentions progressed by Przeworski, Bernstein tracks down that the modernization theory stands up well. Halfway popular governments arise among the most significant and least comprehended system types (Bernstein: 197, 141-60).

As research advanced, scholars developed more measures of democracy; they confirmed the existence of a co-relational relationship (not a causal one) between democracy and development (Bollen \& Jackman: 1985, 6). Their efforts added to the pile of knowledge needed to build on as scholars try to understand democratization. Their studies have been useful in providing data about particular transitions in all corners of the globe. Their studies included all countries for which information about proposed causes of democratization was available (Barro:1996,158). They focused on the connection among improvement and majority rules system as they have recommended horde measures through which development and the spread of instruction; urbanization; and versatility may prompt requests for popular government (Donnell \&Schmitter:1986, 13-21). A considerable lot of their contentions have discovered a connection amongst schooling, and improvement (Barro: 1995, 22), and a connection between the pay portion of the working class and majority rule government. (Acemoglu, et. al: 2005, 1205). Yet, these investigations didn't completely decide causal connections. 
They just expected to be that "if residents of any underdeveloped nation need vote based system and have the necessary abilities, they can accomplish it. However, their exploration had been uncertain" (Barro: 1996, 23 .)

Thusly, researchers have taken the examination in two ways: The originally acknowledged Barro's contention that hypothetical models of the connection don't exist and that advancement of such models ought to be a need of exploration to reveal the connection among democratization and improvement" (Przeworski et.al.:1997, 155-83). They tried collaborations among elites and residents (who might need to impact circulation and accordingly request vote based system as a methods for acquiring impact). They endeavored to recognize the hidden reasons for democratization that relate with improvement, and wound up by tolerating the connection as illustrative expositions. They didn't track down any causal relationship for democratization between the previously mentioned two factors. The subsequent heading guaranteed that worldwide components have assumed a lot bigger part in democratization than prior saw which was a significant takeoff from prior informative models which dismissed the impact of outside factors on democratization in the third world. They accepted that "if worldwide powers majorly affect democratization; for example in the event that there is a connection among global and homegrown components, the rejection of such worldwide elements from prior investigations wasn't right and may clarify a portion of the restricted and opposing outcomes acquired up to this point" (Sweet: 2001, 22-25). To be sure, "Worldwide impacts have seldom figured in the writing on democratization" (Boix:2003, 33)

The previous contentions help us shed light on democratization in Morocco which should be hampered by Islamic inclinations as we will see, nor is it expected to be cut short by absence of financial or political turn of events.

\section{V- Uniqueness of the Moroccan Experiment:}

Before addressing democratization in Morocco and the role of the King in it, this paper proceeds by observing that democracy is a process of continuous growth and a journey that never ends. It is a journey that has a definite beginning but seems to have no end to it. The Americans and the British continue to improve their democracies despite the centuries of democratic practice (Haas: 2014, 23), and neither of these two claims that their democratic ship has come ashore (Heater: 2006, 30-42). Democratization is a process that takes time and effort and requires forbearance and persistence; building continuously on previous achievements. Every democratic gain, no matter how small it may be, ought to be consolidated for a real democracy to take root. Therefore, vigilance against possible setbacks should never be given up where fragile institutions 
and systems exist. This paper sees elections as a definite beginning of democratization and not the end of the process, and that there could be elections without democracy. It is the commitment of the political elite and all interested groups (stakeholders) in any country, to build a democratic society that advances democratization. A country could hold elections without democratizing, whereas one election (good or bad) with the political will of the elite could help consolidate democracy. This always becomes possible when the elite build a consensus toward improving democratic governance.

Morocco has been one of the few countries that really progressed towards democratization. While many Arab countries appeared to suffer from the stalling of elections; thereby inhibiting democratic progress, Morocco has been one of the few countries that managed to benefit from elections. While in many third world countries elections have been used as a way for elite legitimacy and self-perpetuation, Morocco's interest in democratization can never be over exaggerated, nor can it be overlooked or dismissed as irrelevant (Mueller:1996, 17). Thirdly, since pluralism is a central condition for a true democracy, it requires legitimate processes to mediate and regulate multiparty politics and competition. This area, too, has always been problematic in many Arab and African countries.

In Morocco, and due to the role of the King, such processes have been conducive to successive, uninterrupted, successful and incremental democratization. Being the final arbiter of the political system, the King has, over time, been the best 'election manager' capable of conflict resolution as he has always been perceived as being above all political parties. As leaders of Moroccan political parties attempt to minimize post-election conflicts, they always look forward to the King with the highest possible esteem and tone down their differences and quarrels. This enhances the King's impartiality and credibility within the political system. And finally, the legal frameworks for elections in many African and Arab democracies are, sometimes, inconsistent with the liberalism expected in democratic politics. Also, constitutions drafted by incumbents, who desired to stay in power for ever, have tended to retain the old pattern in favor of the entrenched political elite; thereby limiting the range of viable parties and political alternatives despite the existence of pluralism. This leads to serious problems in many African and Arab democracies. In Morocco, however, this issue has been settled by the King who is considered 'the Commander of the Believers'. This is an axiom for all Moroccans and is rarely disputed even by the opposition. Observers noted that the reforms followed the same pattern as previous ones, with the king dictating the terms to docile political parties and elite (Ottaway: 2008, 123). There are also institutional and political traits inherent to the 
Moroccan regime which was not cited by many scholars (Maghraoui: 2001, 12-17). These are: 1-. Political change in Morocco has in numerous events been started by the ruler and was not a simple response to any external pressing factor (for example at the point when the American organization griped against Arab tyrant systems in the fallout of the psychological militant assaults of 2001, the Moroccan system was not planned); as the Moroccan change plan originates before that ghastly occasion and furthermore originates before the episode of the Arab Spring that began later in 2011 (Baudouin: 2014, 6). However, it appeared to be that the flood of the supposed Arab Spring didn't completely apply to the Kingdom of Morocco; 2.- Many researchers have shown that democratization in Morocco is viewed as the result of a long cycle of collaboration among a few key entertainers and organizations, boss among which is the Monarch: An interaction that yielded an exceptional involvement with Africa and the Arab world. However, the job of the King is troublesome as we will see; 3-The Irreversibility of the Process: The second separating component that recognizes Morocco from other African or Arab nations, identifies with the level of irreversibility of the democratization cycle in the Kingdom. The ordinary example of the progress to majority rule government, as the writing on democratization shows, centers around the rehashed endeavors of a change towards vote based system (Carothers: 2002, 5-21). This is considered as a transient cycle (a period with a start and an end) between the separation between two systems: (the undemocratic and the vote based systems (Azouzi: 2006, 107). This hypothetical necessity of the change is frequently affirmed by experimental examination; particularly with respect to the third flood of democratization in Latin America and a few nations in Eastern Europe .

In Morocco, dissimilar to third-wave advances saw by researchers, it is protected to contend that any endeavor to consider the cycle of change through the crystal of the progress worldview is probably going to confront two difficulties: The first is the shortfall of what a few specialists call a breakpoint, or the zero mark of the progress interaction (Elmoumni: 2006, 9). Obviously the1992 and 1996 protected corrections or the alternance allowed in 1998, by and large summoned by the authority way of talking of the change, doesn't stamp breaks or breaks in the working style of the Moroccan system. Elmoumni states: "A long way from being a breakpoint, these occasions can be deciphered as snapshots of bifurcation stamping corrections of the system to adjust to its developing climate, instead of as premises of any equitable change". The subsequent test is the way that regardless of whether one of the occasions referenced beforehand can be viewed as a beginning stage for vote based change in Morocco, it actually 
stays hard to distinguish the stage that the progress has reached up until this point. This uncertainty can be clarified by the shifting of the direction of popularity based development in Morocco's governmental issues. At last, this remaining parts the sign of the political life in Morocco and is by all accounts contradicting to the 'ordered necessities' of the change guarantees that suggest a plan plainly characterized and settled upon by the critical entertainers of such an interaction (Rachik, and Bourqia: 2014, 12).

\section{VI.- The Role of the Monarch:}

Perhaps the first feature in the uniqueness of the Moroccan political system is the salient role of the King. The Moroccan political system shows some peculiarities in as far as the King's power is concerned (Camau:2006, 59-81). His vast powers indicate his central position in the system, and that he owes these powers to many factors that helped him to have that salient role. The Monarch has always been the main and chief architect of any political reform or democratization (Hermet 2012, 285-304). The relationship between the King and his subjects has been unique (Chraïbi: 2019, 3). Any attempts at political reform in Morocco should be seen in the light of this fact that helps us distinguish the democratic transition from other forms of political reforms (Bendourou, \& Aouam: 1993, 431-446). Many scholars referred to two issues that influence democratization: the historical period it takes place in and the type of regime that democracy replaces. The individuals who examined the Moroccan framework have would in general propel a fixed picture of the political scene. Sweet expressed that "Moroccan foundations are unquestionably more liberal than previously. However, none of the progressions under the late King Hassan or King Mohammed has influenced the ruler's rights the government holds supra-institutional forces. There is no instrument for eliminating the ruler from office, shy of unrest. His force isn't liable to change by general society or chose authorities. It would be wrong, then, at that point, to portray Morocco's new political advancement as democratization. In actuality, a significant number of these 'majority rule' changes have hardened the government's situation as the first among establishments" (Sweet: 2001, 22-25).

These readings were tested by the February 20 Movement. The government is positively solid, yet doesn't control the entire scene, and it's anything but viewed as the unparalleled political entertainer on the scene. Henceforth, checking on the issue of governmental issues with common society drove us to inspect the political changes and the basic liberties issue, and to investigate the authoritative interaction of Mohammed VI since 1999. The talk of these entertainers permits a more extraordinary perusing of the government's status, the political framework and the part of other outer entertainers. 


\section{Political Stability and Human Rights:}

Post-frontier Morocco is portrayed by its very own exceptional element: embracing the cutting edge part of French sacred law addressed in a multiparty framework, however not giving up its authentic "nature" in the activity of force. Present day organization is utilized as an instrument of clienteles and simultaneously the framework has kept its noteworthy and customary authenticity. In view of this act of force, political life exists in a complex political framework in which innovation looks after custom. The government controls and controls the political scene and rebuilds its partnerships with the heads of country society just as the elites of the metropolitan culture utilizing strategies of remuneration and estrangement, as "the best way to succeed financially and politically is having the ear of the ruler ... an equilibrium is based on the logical inconsistencies between the various entertainers, while the government fears all sides simultaneously " (Hammoudi: 2001, 4). This equilibrium, held by a strict government that will not share power, permits the last to decidedly mark itself as the exemption in the locale .

Strength, a critical idea in the legislative issues in Morocco, can once in a while be utilized to the detriment of common liberties and majority rules system. Morocco is a government dependent on strict authenticity where the ruler's job is critical. Common liberties are an issue that has consistently been an issue to the Moroccan system. Both nearby and global basic liberties associations have shown that torment, discretionary confinement and constrained vanishing of dissenters are normal in Moroccan political life. This approach of suppression received by the position acquired consideration after the fall of the Berlin Divider. The adjustment of the world request pushed the government to receive new measures in regards to the admiration of basic liberties, and brought about the rise of another political dynamic. Along these lines, in his discourse on 20 August 1992, Ruler Hassan II focused on the need and will of Morocco to adjust to the new world setting by requiring a submission about the new constitution. This constitution perceived without precedent for the historical backdrop of Morocco the significance of regarding common liberties as all around perceived. It was truly a message to the worldwide local area to console it following various reports, especially those introduced by Acquittal Global, featuring different infringement of basic freedoms in Morocco (Bendourou and Aouam: 1993, 431-446.(

The 1990s were the years during which the Moroccan government opened up to the new political time, without extricating its grasp on power. The drives taken by the system principally spun around the foundation of the Warning Board for Common liberties and the Free Assertion Commission for the Pay for Casualties of Upheld Vanishing and Subjective Confinement, 
as well as perceiving the Amazing vernaculars through Al-Hassan II discourse of 20 August 1994, following quite a while of constraint of Amazigh social affiliations. These drives were essential for another procedure received by the political system, intending to acquaint new entertainers with the political scene. The audit of the constitution in 1996 was additionally an apparatus utilized by the government to present changes. In any case, the rule of the decision ruler didn't change; subsequently, the government stays the key political entertainer .

The progression of Lord Mohammed VI to the seat on 23 July 1999 started indeed the discussion in Morocco about the centrality and inescapability of the government. Consequently, numerous political goals surfaced with the delegated of the new lord. Mohammed VI looked for most importantly to accommodate Morocco to its past, and this is the reason he tried to make the Value and Compromise Commission in 2004 whose goal was to open an examination concerning infringement submitted during the rule of Hassan II and to accordingly give pay to the people in question. Notwithstanding the accomplishments of this establishment, its effect stayed restricted as it was under the lord's control. The mission of accommodating Morocco to its past was not accomplished as the Commission received this sober minded vision of compromise which didn't meet the assumptions for basic freedoms safeguards. Hence, this drive was not trailed by the showing the adolescent the contemporary history of Morocco. Furthermore, numerous different issues stayed untouchable including the constrained vanishing of protesters. "Value and Compromise Commission appeared to be to a greater degree a showcasing political system than a stage targeting turning the page on the past and advancing common liberties" (Bendourou:2014, 3). The open entryway strategy received by the government didn't keep going for long after the 11 September 2001 assaults and the Casablanca assaults of 2003; the system then, at that point returned to its dictator recorded nature, as demonstrated by a Moroccan common freedoms association agent as "The vacation with the Makhzen didn't keep going for long. The majority rule opening began in the start of the 1990s with Lord Hassan II be that as it may, the restraint has been continued since the assaults of Casablanca in 2003" (Howe:2000, 65-70). This suppression was at first utilized against the Salafi and Wahhabi developments, yet the government likewise considered it's anything but a chance to rebuild the political scene. (Hammoudi: 2019, 16).

In any case, with the constitution of 29 July 2011, a huge advance was accomplished towards the development of the political cycle in Morocco. The new constitution appears to stop the syndication of force by the ruler. It likewise opened the path for offering capacity to the PM and for the acknowledgment of individual rights. This constitution comes in the wake of 
the Bedouin Spring and meets the assumptions for the political contestation development, i.e., the February 20 Development. This development united common liberties associations as well as youth not partnered with ideological groups, fully intent on setting up a parliamentary government and stopping exemption and delivering of records. (Mouna: 2016, 35-37). The constitution appears to mirror a union of the various requests of common society and ideological groups. However, the inconsistency between the decree of rights and the limitations forced on them is striking to such an extent that getting a charge out of these rights appears to be for all intents and purposes unthinkable (Bendourou:2014, p. 1).

The political life in Morocco is regularly mutilated by political researchers whose jargon has been overwhelmed by certain (dedication/disloyalty, credibility/innovation, solidarity/division, and agreement/conflict). This has been an obstruction to the rise of present day political reasoning that could add to building an ideological group insight in a cutting edge vote based and political importance way. In an investigation expecting to recognize the principle characteristics of ideological groups' involvement with Morocco, Jandari presumed that the absence of philosophical points of view in ideological groups is an aftereffect of the absence of current political practice. This delivered present day ideological groups unfit of building themselves, not to mention prevailing with regards to setting an arrangement dependent on their discretionary stages. Two principle entertainers are portrayed as having the primary job in this powerful of progress: the government and common society (Howe: 2014,70).

\section{2.- The Role of Civil Society:}

Lord Mohammed VI advanced the development of common society which has developed altogether since his rule started. Accordingly, the lord has driven numerous progressions in the nation, beginning with handling the issue of common freedoms. In addition, he set up numerous intermediation organizations to make a political progress conceivable, also the arraignment of Inside Priest Basri, ensnared in a few instances of defilement during the period of Hassan II. The democratization project began by Hassan II was related with the multiplication of ideological groups, which gave the feeling that Morocco was looking to carry out genuine changes to turn into a 
majority rules system. Besides, this receptiveness accompanied a total progression of the Moroccan economy and the section of unfamiliar capital into the nation, exploiting an approach of privatization. This financial advancement made Morocco the main country in the Maghreb locale as far as friendly imbalance, especially since the changes presented in 2011 which permitted the state to decrease its contribution in the pay reserve. These carried out changes supported pluralism kept to a common society which is likely among the most energetic in the Center East. Common society generously affects strategy making particularly in spaces of ladies' and basic liberties; just to allude to the numerous Affiliations which enunciated ladies' privileges and basic freedoms, and embraced a "self-restricting system" that is autonomous of ideological groups. These affiliations addressed change inside Moroccan culture. This change was the aftereffect of a mindfulness about common liberties and the required political changes. However, the state had the option to rule common society by building up in 2005 the Public Human Improvement Drive as an apparatus to oversee common society by allowing assets to affiliations. Yet, in spite of the overall opportunity given to common society, the ruler is as yet seen as inescapable thinking about the absence of political rivalry .

As democratization in Morocco has met political and financial difficulties, Moroccan common society turned out to be dynamic in all areas (Cavatorta:2006, 203-222); subsequently beginning from the issue of basic liberties (Behr:2012,76-88). Moroccan common society met two significant challenges. The initially was that it needed assets and polished methodology; and the second was the centralization of force which has consistently been at the disservice of common society (Bendourou:2014, 165-178). Agreement between all entertainers is an essential to keep away from any test to the political framework that may imperil a real equitable cycle (Behr: 2012, 7688). Inside this unique situation, the EU enters as an outside part in the Moroccan cycle. As democratization in Morocco has gone up against political and financial difficulties. Common society has as of late become exceptionally dynamic in Moroccan culture, working in all areas and beginning from the issue of basic freedoms. Be that as it may, on the grounds that this common society faces two significant troubles (absence of assets and polished skill; and the idea of force and its centralization) political entertainers and social activists could challenge the political framework. This pretty much rules out any fair interaction, and more space for outer players. Hence, the European Association and different entertainers go into play as outer players. The inquiry becomes which job could common society play to turn into a genuine accomplice towards majority rule government?. 
Since the increase of Mohammed VI to the seat in 1999, expects political and financial advancement in Morocco have lingered high as this was seen as the last advance towards a genuine majority rule government. The new lord started making strides that separated him from his dad: permitting resistance figures to return to Morocco; delivering a few heads of protester bunches following a time of house capture; and lifting an authority restriction on exhibitions by comics whose analysis of the system sometimes fell short for the ruler. These were signs that "another Morocco was on the ascent with common society acquiring force". While opening up to majority rules system, delivering political detainees and drafting new laws allowing more rights to ladies, the Moroccan system constantly consolidated moderate common freedoms with centralization of force. It is inside this structure, we investigate the parts of the entertainers and the absence of genuine majority rules system and genuine regard of common liberties in Morocco; The job of the ruler can be additionally delineated through a speedy examination between that job and the jobs played by different powers in the Moroccan culture like common society and the job of the resistance tip top.

\section{A- The Islamists and the Moderates:}

In North Africa, The positive job that a functioning common society plays in democratization is viewed as inconvenient to democratization in light of the fact that the prevailing job is played by Islamist gatherings (Zakaria: 1997, 22-43). The wrongly saw 'uncivil' and undemocratic Islamist ethos of these gatherings ruined the investigation. It is our supposition that Islamist affiliations and gatherings can be a likely power for democratization for three reasons. In the first place, they are fit for political learning; also, they create common society activism as a reaction to their exercises, expanding the quantity of entertainers in the political and social framework; lastly, they can help out other common society bunches on various issues, given that they are altogether dependent upon similar dictator requirements. Here, we center, specifically, working on this issue of Morocco and the Islamist bunch Jamiat al-Adlwal-Ihsan (Durac: 2009, 3-19 .)

There are two primary ways to deal with dissect the current exceptional connection between the government and the Islamists of the Gathering of Equity and Advancement (PJD). The first spotlights on the connection between the PJD and the system. Such a methodology is probably going to permit better comprehension of the way toward coordinating of the Islamists and the long way they have come from the resistance to the ecclesiastical portfolios in the public authority. In any case, this methodology may hazard separating the PJD's political idea and perspectives from the social, political, and institutional climate that contributed in forming them extra time. Notwithstanding the government and the PJD, this climate incorporates 
different entertainers, with various belief systems that ought to be considered while examining the philosophical and political advancement of the PJD. The subsequent methodology comprises of looking to the living together among Islamists and the government as a result and sign of what is alluded to in this article as 'the Moroccan Aggregate Political Psyche'. This implies a bunch of qualities, thoughts, convictions, non-composed principles, propensities, and so on, which are molded by and shape the manner of speaking, political reasoning, and practices of the Moroccan political elites, and their relations with one another and with the majority. The cycle that drove the Islamists of the PJD to incorporate state foundations ought to be viewed as a result of the manner by which resistance groups have associated, after some time, with the government as the focal entertainer of the political framework. It very well may be expected that the moderate Islamists of the PJD have assembled their political plan on some sort of exploitation of the results of the contention between the government and the radicals, particularly during the 1960s and mid-1970s.

\section{B.- The Role of the Left:}

A couple of years after Morocco acquired its freedom, the contention over power between the government and its resistance made the nation enter a political endless loop. This contention arrived at its peak when each side attempted to take out the other; accordingly making the nation go into brutality during the 1960s and 1970s. This period is frequently alluded to as the long stretches of the lead. At the point when Al-Hassan II acquired the seat from his dad in 1961, he embraced a gentler style of restraint that mixed attractive prizes and unforgiving disciplines. His favored strategy was to kill potential force competitors through motivators, for example, liberal land awards, business arrangements, and offers of generously compensated government positions. The idea of Hassan II's standard was to a great extent seen as a system which 'utilizes present day organizations to save archaic political power' (Maghraoui: 2001, 12-17.) (

It is significant that the 1960s and 1970s saw the most noticeably awful maltreatment against saw or likely adversaries. Exchange unionists, communists, intelligent people, ranchers, Islamists (anybody associated with being condemning of the government) might actually be dependent upon a wide scope of disciplines, frequently only for the 'wrongdoing' of a supposed political connection. The political circumstance in Morocco deteriorated in 1970 and 1971 when two fruitless overthrows d'état incited wide-scale captures, military preliminaries, and executions of those idea to be included. In 1973, 58 individuals from the military who got jail sentences were confined until their where passings. The actual preliminaries were for the most part directed with no conventional assurances of reasonable 
preliminaries and, apparently, were trick procedures. Besides, the issue of the vanished individuals reflected one of the strategies that were deliberately utilized by the Moroccan state to dispose of its rivals, regardless of what their political affiliations were. As a result of the environment of dread that portrayed the standard of Hassan II during the 'long stretches of the lead' little data about these infringement was unveiled. Despite the fact that it was clearly uneven, the showdown between the government and the liberal resistance brought about a lose-lose situation. Neither did the ruler prevail with regards to taking out his liberal resistance, nor did the last prevail in its undertaking to topple the government. From one viewpoint, the government understood that what it's anything but a foe ended up being a socially profound established resistance. On the other, the radicals understood that what they thought about a traditionalist, conservative, and moderate system was really a multi-century monarchical framework that had emphatically molded the country's political culture .

The primary element of this culture lies in the qualification between the lord personally and the government as an organization. "While the staggering larger part of Moroccans may consider the ruler actually unmerited or unjustifiable, they in any case relate to the government as an image of public solidarity and authentic type of administration" (Maghraoui:2001b,73-86)

Subsequently, these two focal entertainers of the Moroccan political life began a long and moderate interaction of common acknowledgment and trust building. This interaction was principally set apart by their readiness to rise above their resistance and turn the page of their shared rejection previously. The rise of another political cognizance has prepared for these previous adversaries to begin making huge concessions that will turn into the first and novel experience of Temporary Equity in the Middle Easterner World up until this point .

These changes made ready for the formation of the Autonomous Discretion Commission accused of deciding various degrees of remuneration for instances of self-assertive detainment and authorized vanishing that happened somewhere in the range of 1956 and 1999. This was one of the reasonable indications of the change that happened in the manner the government and the radicals see one another. Clearly the two of them have bombed in crushing each other. Regardless, this disappointment has brought forth critical achievement in figuring out how to manage each other in a nonconflictual way. As such, they appear to have become profoundly persuaded that contention turns into dead end. This exercise could be viewed as another key component that advanced the Moroccan Aggregate Political Psyche. The positions received by the current heads of the PJD towards the government 
show that: "It is the leader who carries out the constitution" (Benkirane: 2014, 4).

In December 2011, not long after the consequences of the authoritative decisions were delivered, Lord Mohamed VI selected Benkirane, Secretary General of the PJD, as top of the public authority. While a few eyewitnesses described this arrangement as an extraordinary defining moment that gives the possibility of 'the Moroccan excellence' substantial substance (Charles:2013, 23), others, less idealistic, have accepted that such an occasion is probably going to be the initial phase in what they considered a political move targeting evading the Bedouin Spring (Madaniet. al. 2012, 34). Despite what the aims and assumptions for the government and the PJD were, the quiet and smooth joining of Morocco's Islamists is without a doubt an uncommon involvement with the Bedouin world .

This article contends that the new job the Islamists are playing in the post2011 period ought to be viewed as a result of a long cycle of political realizing, which has driven the Islamists of the PJD to make two bursts: a philosophical crack that comprised in receiving another method of reasoning, and they additionally made a political break that caused them to acknowledge political support dependent on mainstream rules of the game (Amghar: 2019, 7 .(

As opposed to the instance of Muslim Fellowship and the Al-Wassat Gathering in Egypt, there was no huge contest between the PJD and other Islamist gatherings. For example, in spite of the fact that it's anything but an alternate political position in regards to the government, the JC bunch supposedly admonished its supporters to decide in favor of the PJD competitors in the last administrative races. Given that the idea of outlining measures isn't sufficient to the situation of the PJD, this article endeavors to utilize the idea of 'new intuition' to reveal insight into the PJD's balance interaction. It tends to be characterized as 'a difference in convictions (or the level of trust in one's beliefs)or the advancement of new convictions, abilities, or systems because of perception and understanding of involvement (Levy:2013, 279-312). The idea of Islamists' New Reasoning is seen because of a cycle of political learning of Islamist developments. In light of Duty's definition, it is pertinent to investigate how the Islamists of the PJD have prevailing with regards to moving from a kind of 'upset' philosophy to accepting political interest. It very well may be contended that Moroccan Islamists were first affected by certain figures of political Islam in the Levant. The political edge of reference of the heads of the Moroccan Al- 
Shabiba Al-Islamiyya, which could be considered as the favorable place of the current PJD, was formed by the thoughts of the Egyptian researcher Sayed Qotb. Subsequently, the Islamists ruled out arrangement and discourse. "The main target that was engrossing the Islamist development was to attempt to persuade the individuals who have a place with Al-Shabiba Al-Islamiya that the prominent peril that undermines the Islamic activity was the two socialist communist associations of 'IlaAlamam' and '23 Walk'. These two associations were considered as being impacted and invaded by Jews consequently the issue (the contention) had a philosophical and obstinate measurement" (Talidi:2008, 23 .)

From this, one presumes that toward the starting Moroccan Islamists were somewhat extremist: exceptionally hesitant to attempt any sort of political cooperation or political activity as their definitive goal was to Islamize the whole society. Their adaptation of Al-Islam appears to have been unmistakably motivated by the originations winning in Egypt with the ascent of Muslim Fraternity bunch. Their relations with the express, the general public, and different parts of the political field were tense.

\section{C.- The Role of the Elite:}

The Moroccan tip top have an influence in this interaction. "the Moroccans are 'not absolutely latent and are progressively turning out to be an integral part of the cycle of progress'. To a degree, this continuously affirms ends came to by numerous researchers such that legislative issues stays the 'safeguard of the elites' in Morocco, yet in addition in the whole Maghreb by and large" (Willis: 2012, p. 70). Nonetheless, the part of the Ruler in the democratization cycle has been challenged by resistance pioneers. "the Moroccan Lord has a job undoubtedly in democratization; that of annihilating majority rule government by and large; by demanding holding supreme force and on the debilitating of the resistance" He censures the Ruler for recognizing himself with the Prophet of Islam to fashion loyalty with respect to his easygoing subjects, "This is my direction: I welcome unto Allah with sure information, I and whoever follows me" (Benchemsi: 2019, $3)$. Remarking on that discourse, Benchemsi says: "It's anything but a nerve to distinguish oneself with the prophet Muhammad and contrast a political change with Allah's way. It's anything but a conundrum, coming from a ruler who is evidently about to start revoking his own heavenly right" (Benchemsi: 2019 , 4) . The occasions of 2011 , pretty much, showed that a few contributions from society to the 'development of the post-autonomy state' as a political cycle (previously altogether involved by elites) are gradually giving indications of well-known investment, and the twentieth February Development, among worker's organizations, ideological groups, 
understudies, and so forth, are just models applicable to slow majority rule government referred to in Morocco.

\section{Conclusion:}

The Moroccan political framework is perceived as a result of exchange between the lord and the resistance. The castle appears to have gained from its involvement in its previous liberal rivals that conflict with adversaries is probably going to cause polarization in the Moroccan culture. Subsequently, the government decided on exchanges with them with the end goal of coordinating them into legislative issues. The Islamists, and the radicals in the past were looking for a lose-lose situation. Presently, because of the strategies of the lord, they embrace reasonable political reasoning. They have gotten more willing to make concessions looking for a shared view with different segments of the political circle in a manner that has empowered them to move from the upset philosophy to accepting political investment .

Long time has passed since the new constitution came into power, however it is exceptionally difficult to expect that the eventual fate of democratization in Morocco is prospering. What is sure is that the association between the Islamists and the government has uncovered the job of majority rule mentalities got from neighborhood esteems and customs of resistance in molding the democratization cycle in the country. In fact, the smooth and serene political interaction in progress in Morocco's post-Middle Easterner Spring time is for the most part because of the extensive cycle through which the government is progressing nicely. We note the accompanying :

1. The possibility of a Composite Society can best depict the social, monetary, and social life, which shape the conduct of Moroccan system .

2. The making of a second office of parliament with practically similar privileges of the Place of Delegates, has specifically the opportunities for the obligation of the public authority ;

3. The Ruler has had the option to train all powers of resistance .

4. Decisions have gotten more straightforward, and residents delighted in expanding opportunities to condemn the individuals who represented them, both in the press and in open get-togethers. In the field of common freedoms, the system has delivered a portion of its political detainees ;

5. The Ruler is amazing and he gives orders for the whole political framework. This doesn't appear to be reversible soon of Morocco ;

6. The Ruler has breathtakingly tamed all types of resistance as he controls the entirety of his rivals; and Democratization in Morocco is continuing, prospering and acquiring security. 


\section{Bibliography:}

1. Adekola A A 2010. Democratic Development, in Nigeria since independence: Challenges and Prospects. Ibadan: College Press and publisher Ltd.

2. Amghar, Samir, Political Islam in Morocco Center for European Policy Studies Working Document 269.

3. Archibugi, Daniele 2008. The Global Commonwealth of Citizens. Toward Cosmopolitan Democracy, Princeton University Press, Prince

4. Azouzi, Abdelhak, 2012. Autoritarismeet Aléas de la Transition Démocratique dans Les Pays du Maghreb, Paris: L'Harmattan.

5. Brumberg, Daniel, "Democratization in the Arab World? The Trap of Liberalized Autocracy" Democracy:13 (4), 2002, pp.56-68.

6. Carothers, Thomas. "The End of the Transition Paradigm." Journal of Democracy 13 (1), 2002. pp.5-21.

7. Diamond, Larry, "Why are there no Arab Democracies." Journal of Democracy 21 (1),, 2010, pp. 93-104.

8. Dupret, Baudouin, \& Jean Ferrié, The Moroccan Constitution of July 2011. L'Institut European, iemed.org/publicacions/historic-depublicacions/Accessed Sept. 30, 2019.

9. Fukuyama Francis. (1992). The end of history and last man: Newyork penguin.

10. Hermet, Guy, "Les Démocratisations au Vigntième Siècle: Une Comparaison Amérique Latine/Europe de L'Est." Revue Internationale de Politique Comparée 8 (2), 2001, pp. 285-304.

11. Huntington S. 1997 "After Twenty Years: The future of the Third Wave" Journal of democracy, Oct Vol. 8, No 4. 
12. Huntington, Samuel, 1991, The Third Wave, Democratization in the Late Twentieth Century, Norman: Uni. of Oklahoma Press,

13. Kienle, Eberhard, 2001, A Grand Delusion: Democracy and Economic Reform in Egypt. Londres: Touris, Levy. "Learning and Foreign Policy: Sweeping a Conceptual Minefield." International Organization 48 (2), 1994, pp. 279-312.

14. Lipset, Seymoure.1959, "Some Social Requisites of Democracy ", The American Political Science Review: 53 (): pp. 69-105.

15. Madani, Mohamed 2012, The 2011 Moroccan Constitution: A critical Analysis, International Institute for Democracy \& Electoral Assistance. Stockholm: IDEA,

16. Maghraoui, Abdeslam. "Monarchy and Political Reform in Morocco." Journal of Democracy 12 (1), 2001b. pp. 73-86.

17. Maghraoui, Abdeslam. "Political Authority in Crisis." Middle East Report 218, 2001a, pp. 12-17.

18. Mamdani Mohamed. 2000 Democratic Theory and Democracy Struggle in (Africa) in O. Nnoli (eds) Gov't and Politics in Africa: A reader (Harare: AAPS Books)

19. Monshipouri M. 1995. Democratization, Liberalization and Human Rights in the Third World. London. Lynn Reinner

20. O'Donnell, Guillermo, and Philippe C. Shmitter, 1986. Transitions Authoritarian Rule: Tantative Conclusions about Uncertain Democracies. London: The Johns Hopkins University Press,

21. Opgenhaffen, Veerle, \& Mark Freeman, 2005. Transitional Justice in Morocco: A Progress Report. New York: International Center for Transitional Justice,

22. Ottaway, David, 2019, "Morocco's Islamists: In Power without Power." W Wilson International Center for Scholars, Viewpoint 2012, Series 5. islamists in power without_power_1.pdf. Accessed on September 10,

23. Ottaway, Marina, 2013. Democracy Challenged, The Rise of SemiAuthoritarianism. Washington, DC: Carnegie Endowment for International Peace

24. Ottaway, Marina, and Julia Choucair-Vizoso, ed. 2008, Beyond the Facade: Political Reform in the Arab World.Washington,DC: Carnegie Endowment for International Peace,

25. Sadiki, Larbi. 2019 Rethinking Arab Democratization: Elections without Democracy. Oxford : Oxford University Press,.

26. Tozy, Mohamed. 1999, Monarchieet Islam politique au Maroc. Paris: Presse de sciences.

27. Willis, Michael J., 2012, Politics and Power in the Maghreb: Algeria, Tunisia and Morocco from Independence to the Arab Spring. New York: Columbia University Press,. 